\title{
114. Sicherheit in der Dickdarm-Chirurgie durch dreizeitiges Vorgehen nach Schloffer
}

\author{
H. Geisbe*, W. Dick, Sen., W. Dick, Jr., L. Koslowski \\ und C. Th. Ehlers-Tübingen
}

\section{The Greater Safety of Schloffer's Three-Stage Procedure in Colon Surgery}

Summary. The results of treatment in 252 carcinomas of the colon, aboral of the left flexure and 60 resections of the rectum, some with abdominal and some with sacral anastomoses, are reported. All the patients had been admitted for treatment to the Surgical University Clinic, Tübingen, between 1955 and 1967.

Of 168 cases where radical resection was possible, 139 were operated according to Schloffer's 3-stage method, and 29 had one-stage operations. Of 139 patients who underwent 3 -stage operations, one died $(=0.7 \%$ prim. op. mortality $)$ and of the 29 primary resections, 3 patients died ( $=10 \%$ mortality). On comparing this with the corresponding literature, it is shown that the laborious Schloffer method gives maximum safety, while the total number of resections performed is kept high $(72.5 \%)$.

Long-term results are given, related to the stage of the tumour (according to the TNM classification) and based on 5-year survival curves. $73 \%$ of the patients operated on in Stages I and II survived the 5-year survival line, but only $40 \%$ of the patients treated in Stage III and $16 \%$ of those treated in Stage IV survived the 5 years. $55 \%$ of all the patients who underwent radical resection reached the 5-year limit.

Zusammenfassung. Es wird über die Behandlungsergebnisse von 252 Coloncarcinomen aboral der linken Flexur und 60 Rectumresektionen mit zum Teil abdominellen, zum Teil sacralen Anastomosen berichtet, die zwischen 1955 und 1967 an der Chirurgischen Universitäts-Klinik Tübingen stationär aufgenommen wurden.

Von 168 radikal möglichen Kontinuitätsresektionen wurden 139 dreizeitig nach Schloffer, 29 einzeitig vorgenommen. Nach 139 dreizeitigen Resektionen verstarb 1 Patient $(=0,7 \%$ prim. Op.-Letalität), nach 29 prim. Resektionen kamen 3 Kranke ad exitum $(=10 \%$ Letalität $)$.

Aus Vergleichen mit entsprechenden Literaturangaben ergibt sich, daß die umständliche Schloffersche Methode maximale Sicherheit bietet bei einer hohen Gesamtresektionsquote $(72,5 \%)$.

Die Spätergebnisse wurden in Abhängigkeit vom Tumorstadium (nach der TNM-Klassifikation) anhand der 5-Jahresüberlebenskurven dargestellt: $73 \%$ der in Stadium I und II operierten Patienten überlebten die 5-Jahresgrenze, aber nur $\mathbf{4 0} \%$ der in Stadium III und $16 \%$ der in Stadium IV behandelten Fälle. $55 \%$ aller radikal Resezierten erreichten die 5-Jahresgrenze.

Präsident: Ich darf vielleicht auch darum bitten, auf lange Erläuterungen der Statistiken zu verzichten und uns die tatsächliche Zusammenfassung mitzuteilen. 